\title{
Seasonality in cell and tissue-level biomarkers in Mytilus galloprovincialis: relevance for long-term pollution monitoring
}

\author{
Larraitz Garmendia, Manu Soto, Miren P. Cajaraville, Ionan Marigómez* \\ ACBET Ikerketa-Taldea, Zoologia eta Biologia Zelularra Saila, Zientzia eta Teknologia Fakultatea, UPV/EHU, \\ Sarriena auzoa Z/G, 48940 Leioa-Bizkaia, Spain
}

\begin{abstract}
Mussels Mytilus galloprovincialis were collected monthly in 2 localities in the Northern Iberian Peninsula, Oia (Galicia) and Mundaka (Basque Coast), from April 2005 to May 2006, to investigate whether seasonal variability in biomarkers follows the same pattern at both geographical areas. The following battery of biomarkers was analysed: lysosomal membrane stability and structural changes, intracellular neutral lipid accumulation, cell type composition in the digestive gland epithelium, structural changes of digestive alveoli and digestive gland histopathology. Additionally, gonad index was measured as a supporting parameter. Overall, results demonstrate that most studied biomarkers showed similar seasonal variability pattern in both localities. Lysosomal membrane stability (labilisation period [LP]) and most histopathological conditions showed similar seasonal variability patterns in both localities, although values of LP and prevalences of some parasites were higher in Mundaka. Data provide baseline values to be used as reference values for the biomonitoring programmes carried out in coastal areas from Galicia to the Basque Coast. It is concluded that for monitoring programmes based on biomarkers, samples must be taken at least twice per year (spring and autumn) to avoid the effect on biomarkers of the late stages of each reproductive cycle.
\end{abstract}

KEY WORDS: Biomarkers $\cdot$ Biomonitoring programmes $\cdot$ Seasonality $\cdot$ Mussel $\cdot$ Galicia $\cdot$ Basque Coast

Resale or republication not permitted without written consent of the publisher

\section{INTRODUCTION}

Mussels and other marine bivalves are widely used as sentinel organisms to assess the health of coastal and estuarine environments (Stagg 1998, UNEP/RAMOGE 1999, Cajaraville et al. 2000). They are filter-feeding organisms, sedentary, able to tolerate a wide range of environmental conditions, including exposure to xenobiotics, and show a low ability to metabolise xenobiotic compounds, accumulating them in their tissues at high levels (Oehlmann \& Schulte-Oehlmann 2003). On exposure to pollutants, mussels respond in a way that can be measured through biological effect biomarkers including histopathological alterations (Marigómez et al. 2006, Orbea et al. 2006). Biomarkers are considered early warning signals for the assessment of ecosystem health. The determination of early biological changes may be useful to detect predictable long-term physiological disturbances (McCarthy \& Shugart 1990). Histopathology, which often refers to durable effects, and may reflect individual condition and fitness, can help to interpret molecular and cell biomarkers, thereby acting as a reference against which true effects of historic exposure can be assessed (Bignell et al. 2008).

Seasonality is crucial for the design and interpretation of results in pollution monitoring programmes based on biomarkers (Cajaraville et al. 2003, Bocchetti et al. 2008). The values of biomarkers and the incidence of histopathological alterations can be influenced by environmental factors that vary seasonally such as temperature, food availability and salinity, and may also change throughout the reproductive cycle 
(Cancio et al. 1999, Svärdh \& Johannesson 2002, Shaw et al. 2004, Bocchetti \& Regoli 2006, Bignell et al. 2008, Verlecar et al. 2008). Accordingly, geographical differences in biomarker values can be associated with varying environmental factors and reproductive cycles (Marigómez et al. 1996, Cancio et al. 1999, Ivankovic et al. 2005, Leiniö \& Lehtonen 2005, Izagirre et al. 2008).

In the monitoring programmes designed to assess the biological effects of the Prestige Oil Spill (POS) that were carried out from Galicia to the Basque Coast (Northern Iberian Peninsula), mussels Mytilus galloprovincialis were selected as sentinels (Marigómez et al. 2006, Orbea et al. 2006). A battery of exposure and effect biomarkers was employed, including lysosomal membrane stability (labilisation period) and lysosomal structure (lysosomal volume density, surface-to-volume ratio and numerical density) (Moore 1988, Marigómez \& Baybay-Villacorta 2003), intracellular neutral lipid accumulation (volume density of neutral lipids) (Moore 1988, Lowe \& Clarke 1989, Regoli 1992, Marigómez \& Baybay-Villacorta 2003), cell type composition in the digestive gland epithelium (volume density of basophilic cells) (Cajaraville et al. 1990, Marigómez et al. 1998), structural changes of digestive alveoli (mean luminal radius to mean epithelial thickness) (Vega et al. 1989, Cajaraville et al. 1992) and digestive gland histopathology (Kim et al. 2006).

During the first year after the spill, the marked differences in biomarker values found among localities and sampling times were associated with the POS impact (Marigómez et al. 2006, Orbea et al. 2006). However, differences among localities and sampling periods were not so pronounced during the subsequent longterm effects monitoring (Garmendia 2008). Therefore, it was difficult to determine whether these differences could be attributed to POS or if they might reflect just geographical differences in baseline biomarker values along the study area ( 1000 km coastline). The possibility that different species or hybrids of different species of the genus Mytilus inhabit the various studied localities has been discarded (Garmendia 2008). However, environmental factors such as temperature, rainfall, primary production and tidal regime, and their seasonal variations, vary markedly from Galicia to the Basque Coast (García-Soto et al. 2002). It is therefore conceivable that the physiological and pathological condition of mussels might be naturally different along the study area, which might affect biomarkers in those instances in which pollution impact is not as marked as immediately after the POS. Reference values for some biomarkers studied herein have been previously reported for the Basque Coast (Marigómez et al. 2006); however, as far as we know, previous data in Galicia are lacking and the existing baseline values cannot be extended to the whole area affected by the POS.
Thus the present study was carried out in order to determine baseline values for the biomarkers employed during the POS monitoring programme, their seasonal variability and how environmental factors might affect biomarkers in different geographical locations within the study area. For this purpose, 2 model localities were selected: Oia in Galicia and Mundaka on the Basque Coast. Both localities are under the influence of the OSPAR Convention, whose Joint Assessment and Monitoring Programme (JAMP) utilises biomarkers for monitoring biological effects (Stagg 1998). Likewise, gonad index was measured as supporting parameter, as seasonal dissimilarities in biomarkers might be attributed to variations in the reproductive cycle among mussel populations. Although we were aware of the need for baseline data since the very preliminary studies (Cajaraville et al. 2006, Marigómez et al. 2006, Orbea et al. 2006), this investigation had to be postponed until 2005-2006, once signals of recovery after the POS had been evidenced in 2004-2005 (Cajaraville et al. 2006).

\section{MATERIALS AND METHODS}

Study locations. Mussels Mytilus galloprovincialis were collected monthly from Oia $\left(42^{\circ} 0^{\prime} 15^{\prime} \mathrm{N}, 8^{\circ} 52^{\prime} 48^{\prime} \mathrm{W}\right.$; Galicia) and Mundaka (43 24' 16' N, $2^{\circ} 41^{\prime} 43^{\prime}$ W; Basque Coast) from April 2005 to May 2006. Oia is located in a rural coastal area and Mundaka may be considered a non-polluted site (Orbea \& Cajaraville 2006). The POS effects were deemed to be minimal during the study period since most biomarkers started to recover in mid-2004 and throughout 2005 (Cajaraville et al. 2006, Garmendia 2008).

Natural factors varying throughout the study period in marine areas representative of each locality $\left(42^{\circ}\right.$ to $43^{\circ} \mathrm{N}, 9^{\circ}$ to $10^{\circ} \mathrm{W}$ in Galicia; $43^{\circ}$ to $44^{\circ} \mathrm{N}, 2^{\circ}$ to $3^{\circ} \mathrm{W}$ in the Basque Country), such as water surface temperature, average monthly rainfall, tide amplitude and food availability (phytoplankton concentration) are illustrated in Fig. 1 (data provided courtesy of C. GarcíaSoto, Instituto Español de Oceanografía, Santander, Spain). Seasonal changes in water surface temperature were similar in both localities during the study period (highest values in summer and lowest in winter and early spring), but the range of temperature change was higher on the Basque Coast (warmest in summer and coolest in winter) than in Galicia. Average monthly rainfall varies in parallel through the year in both localities, although values are higher on the Basque Coast than in Galicia. Tide amplitude also varies in parallel at both localities throughout the year, but values are higher on the Basque Coast than in Galicia. The levels and seasonal variability in phytoplankton concentra- 
tion differ markedly between both localities. In Galicia, phytoplankton concentration varied between 0.35 and $1.87 \mathrm{mg} \mathrm{m}^{-3}$ and the maximum value was recorded in August 2006 (2.60 $\left.\mathrm{mg} \mathrm{m}^{-3}\right)$. On the other hand, on the Basque Coast, values were quite similar through the year $\left(0.27\right.$ to $\left.0.68 \mathrm{mg} \mathrm{m}^{-3}\right)$, with the maximum value in March 2006 (2.60 $\mathrm{mg} \mathrm{m}^{-3}$ ).

Sampling strategy and processing. In each locality, 10 mussels (3.5 to $4.5 \mathrm{~cm}$ shell length) were collected, and processing began immediately after sampling. The digestive gland of each mussel was dissected out and divided into 2 portions. One portion and a piece of mantle of the same mussel were fixed in $4 \%$ formaldehyde containing $0.1 \mathrm{M}$ phosphate buffer and maintained in the fixative until processing continued (usually within $1 \mathrm{wk}$ ). The other portion of the digestive gland was placed in plastic chucks for cryoprocessing. In each plastic chuck, the digestive glands of 5 mussels were placed in a straight row (2 sets per sample), introduced in cryovials and directly frozen in liquid nitrogen. Frozen samples were transported to the laboratory in liquid nitrogen and then stored at $-80^{\circ} \mathrm{C}$ until required for analyses. Coded labels were assigned to the samples to avoid the subjectivity of the operators in measuring the different biomarkers.

Lysosomal membrane stability. The lysosomal membrane stability test was performed according to UNEP/ RAMOGE (1999). Cryotome serial sections (10 $\mu \mathrm{m}$ thick) from 5 mussel digestive glands were cut in a Leica CM 3000 cryostat (Leica Instruments) and stained for the histochemical demonstration of $\mathrm{N}$ acetyl- $\beta$-hexosaminidase activity. Labilisation period (LP; min) of the lysosomal membrane was established according to the time of acid labilisation required to produce the maximum staining of lysosomes. Although 2 maximum staining peaks were observed in some cases, the first peak was always selected. The mean value, determined for 4 measurements made in each individual, was obtained for each mussel digestive gland (UNEP/RAMOGE 1999).

Lysosomal structural changes. In order to quantify changes in lysosomal structure, digestive gland cryotome sections ( $8 \mu \mathrm{m}$ thick) of 5 mussels were cut in a Leica CM 3000 cryostat and stained for the histochemical demonstration of $\beta$-glucuronidase activity according to Cajaraville et al. (1991). Using a 100× objective lens, 5 measurements were made for each individual using image analysis (Sevisan). The mean value of the following stereological parameters was determined for each mussel digestive gland (Lowe et al. 1981): lysosomal volume density $\left(\mathrm{Vv}_{\mathrm{L}}=\mathrm{V}_{\mathrm{L}} / \mathrm{V}_{\mathrm{C}}\right)$, lysosomal surface density $\left(\mathrm{Sv}_{\mathrm{L}}=\mathrm{S}_{\mathrm{L}} / \mathrm{V}_{\mathrm{C}}\right)$, lysosomal surface to volume ratio $\left(\mathrm{S} / \mathrm{V}_{\mathrm{L}}=\right.$ $\left.\mathrm{S}_{\mathrm{L}} / \mathrm{V}_{\mathrm{L}}\right)$ and lysosomal numerical density $\left(\mathrm{Nv}_{\mathrm{L}}=\mathrm{N}_{\mathrm{L}} / \mathrm{V}_{\mathrm{C}}\right)$, where $\mathrm{V}$ is volume, $\mathrm{S}$ is surface area, $\mathrm{N}$ is number, $\mathrm{L}$ is lysosome and $\mathrm{C}$ is digestive cell cytoplasm.
Intracellular accumulation of neutral lipids. In order to quantify the intracellular accumulation of neutral lipids, digestive gland cryotome sections $(8 \mu \mathrm{m}$ thick) of 5 mussels were cut in the Leica CM 3000 cryostat and stained using the method of Lillie \& Ashburn's Oil Red O (ORO) (Culling 1974). Slides were viewed at $40 \times$ magnification. Five measurements were made by image analysis (Sevisan) to calculate the volume density of intracellular neutral lipids in digestive cells $\left(\mathrm{Vv}_{\mathrm{NL}}=\mathrm{V}_{\mathrm{NL}} / \mathrm{V}_{\mathrm{C}}\right)$ (Marigómez \& Baybay-Villacorta 2003).

Tissue-level biomarkers and histopathology of the digestive gland. In order to measure tissue-level biomarkers and histopathological alterations in digestive alveoli, digestive gland samples (10 for each locality and season) were fixed in $4 \%$ formaldehyde containing $0.1 \mathrm{M}$ phosphate buffer at $4^{\circ} \mathrm{C}$ for $1 \mathrm{wk}$, dehydrated in a graded ethanol series, cleared in methyl benzoate, rinsed in benzene and embedded in paraffin. Histological sections $(7 \mu \mathrm{m})$ were cut using a rotary microtome (Leitz 1512) and stained with hematoxylin and eosin (H\&E).
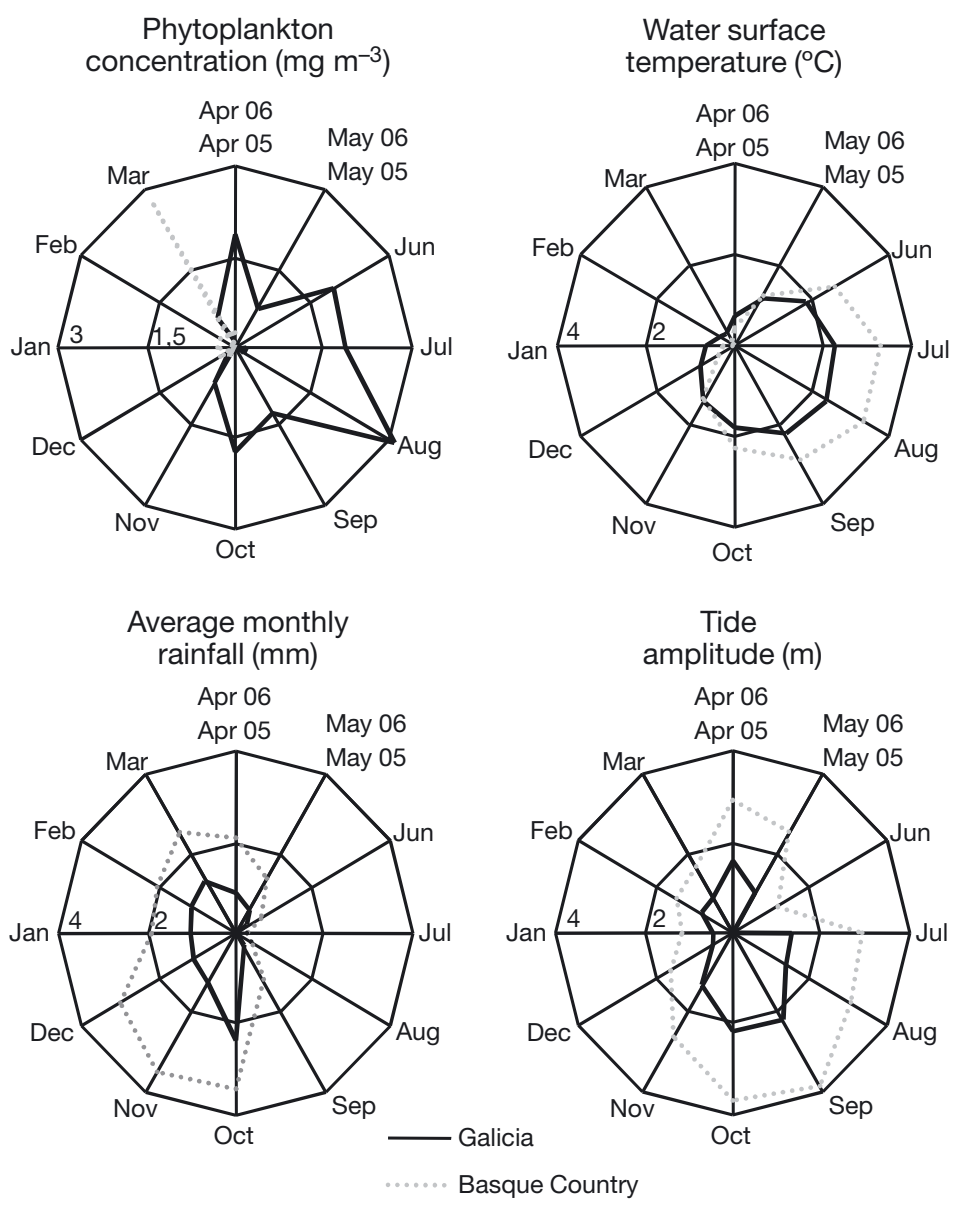

Fig. 1. Seasonal changes in natural factors (phytoplankton concentration, water surface temperature, average monthly rainfall and tide amplitude) recorded by buoys in the marine area of Galicia ( $42^{\circ}$ to $43^{\circ} \mathrm{N}, 9^{\circ}$ to $\left.10^{\circ} \mathrm{W}\right)$ and the Basque Coast $\left(43^{\circ}\right.$ to $44^{\circ} \mathrm{N}, 2^{\circ}$ to $\left.3^{\circ} \mathrm{W}\right)$ from April 2005 to May 2006 
A stereological procedure (Soto et al. 2002) was applied in order to quantify the volume density of basophilic cells $\left(\mathrm{Vv}_{\mathrm{BAS}}\right)$. Counts were made in one field per slide in 10 slides per sample, each slide containing an individual mussel digestive gland. Slides were viewed at $20 \times$ magnification using a drawing tube attached to a Leitz Laborlux S Optiphot microscope. A Weibel graticule (multipurpose test system M-168; Weibel 1979) was used, and hits on basophilic cells and remaining digestive epithelium were recorded to calculate $\mathrm{Vv}_{\mathrm{BAS}}$ according to Delesse's principle (Weibel 1979).

On the same slides, a planimetric procedure was applied to quantify changes in size and shape of the digestive alveoli. A total of 50 tubular profiles per sample (2 profiles per field, 5 fields per mussel, 5 mussels per sample) were recorded in an image analysis system (Visilog 5.4 Noesis) attached to an Olympus BX51 light microscope using a $20 \times$ objective lens. The 5 measurement fields were selected at given intervals throughout the tissue section, the direction of movement always following a zigzag pattern. Mean epithelial thickness $\left(\mathrm{MET}_{;} \mu \mathrm{m}\right)$ and mean luminal radius $\left(\mathrm{MLR}_{i} \mu \mathrm{m}\right)$ were quantified in order to calculate the ratio MLR/MET ( $\mu \mathrm{m} \mu \mathrm{m}^{-1}$ ) as an integrative measure of changes in the alveolus morphology (Vega et al. 1989).

Parasites, diseases and tissue lesions were examined in the same tissue sections under the microscope using a $10 \times$ objective lens. If any tissue needed to be examined more closely, a 20 or $40 \times$ objective was used for closer examination of suspected pathologies or parasites. The recorded histopathological alterations were scored using either a quantitative or semi-quantitative grading scale (Kim et al. 2006) to estimate prevalence $(\mathrm{P} ; \%$ of individuals infected by a specific parasite or presenting a given pathological lesion) and intensity of the lesion (LI) in each individual.

Gonad index. Fixed mantle tissues of 10 mussels per sampling locality were dehydrated in ethanol and embedded in paraffin. Histological sections $(7 \mu \mathrm{m})$ were cut with the rotary microtome Leitz 1512 and stained with H\&E. The gonad index (GI) was assigned based on subjective grading (numerical value) of the developmental stage of the follicles and gametes (Hillman 1993).

Statistical analyses. Statistical analyses were made using SPSS v. 14.0 software (SPSS). Homogeneity of variance (Levene's test) as well as normality of data (Kolmogorov-Smirnov test) were tested before statistical analysis (Sokal \& Rohlf 1995). As a result, $\mathrm{Vv}_{\mathrm{L}}$ and $\mathrm{Nv}_{\mathrm{L}}$ were log-transformed before statistical analysis. The effects of month, locality and their interaction on the different parameters were tested by 2-way ANOVA. In the case of non-parametric parameters (LP and GI), Friedman's test was applied. Furthermore, a Student's $t$-test was used for $\mathrm{Vv}_{\mathrm{L}}, \mathrm{S} / \mathrm{V}_{\mathrm{L}}, \mathrm{Vv}_{\mathrm{NL}}, \mathrm{Vv}_{\mathrm{BAS}}$, and MLR/MET to determine statistically significant differences among localities in each sampling month. The Mann-Whitney $U$-test was performed for LP and GI. Differences among studied localities in the $\mathrm{P}$ of histopathological alterations were tested using the $\chi^{2}$ test. Statistically significant differences in $V_{v_{L}}, S / V_{L}$, $\mathrm{Vv}_{\mathrm{NL}}, \mathrm{Vv}_{\mathrm{BAS}}$ and MLR/MET among sampling months for each locality were tested according to Duncan's post hoc test based on 1-way ANOVA. In the case of LP, the Mann-Whitney $U$-test was performed after non-parametric ANOVA (Kruskal-Wallis). A 95\% significance level $(p<0.05)$ was established for all statistical analyses carried out. Correlations among biological and physico-chemical parameters were performed using Pearson's test for parametric variables and Spearman's rank correlation for non-parametric variables.

Finally, in order to identify the biological parameters that explained seasonal variability, a principal component analysis (PCA) was run. The identified variables were used to perform a classification study of the studied samples based on hierarchical cluster analysis, derived from squared Euclidean distance similarity matrices, after standardised with the z-score method.

\section{RESULTS}

\section{Gamete development}

Overall, gamete development occurred in parallel in males and females both in Oia and Mundaka. In both localities, early gametogenic stages progressed in autumn and early winter and mussels became ripe through winter and early spring (Fig. 2). Spawning started in May 2005 and March 2006 in Oia and in May 2005 and April 2006 in Mundaka. A new gametogenesis cycle started in October. In agreement, according to the Friedman's test, GI significantly changed with month and month $\times$ locality but not with locality (Table 1). Thus GI values varied in parallel in both localities, with a marked decrease after May in Oia and June in Mundaka as a result of spawning. Later in the year, GI values rose again in Mundaka to reach maximum peak values in August and September and then decreased in October as a result of a second massive spawning (this did not take place in Oia) (Fig. 2). A significant negative Spearman's rank correlation coefficient was found between GI and the water surface temperature $\left(\mathrm{r}_{\mathrm{S}}=-0.877, \mathrm{p}<0.001\right)$.

\section{Lysosomal membrane stability}

According to Friedman's test, LP significantly changed with month, locality and their interaction (Table 1). 

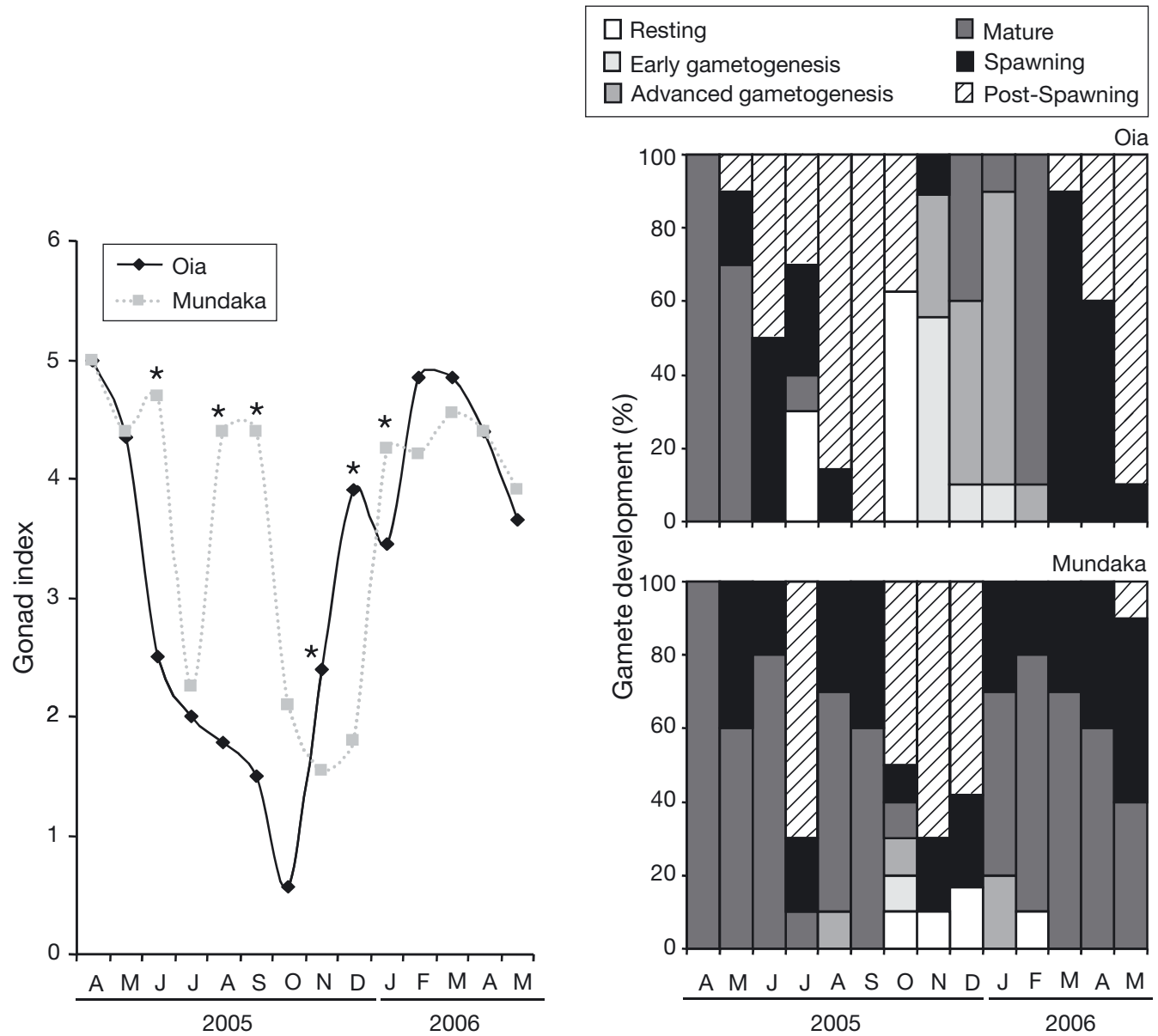

Fig. 2. Mytilus galloprovincialis. Gonad index (GI) and percentage of gamete development stages in mussels sampled monthly in Oia and Mundaka from April 2005 to May 2006. * Significant differences $(p<0.05)$ between GI values recorded in Oia and Mundaka

Table 1. Summary of the Friedman's test performed to analyse the effects of month, locality and their interaction on the studied parameters in mussels Mytilus galloprovincialis sampled at Oia and Mundaka from April 2005 to May 2006. LP: labilisation period of the lysosomal membrane; GI: gonad index; R/CLO: Rickettsia/Chlamydia-like organisms; P: prevalence; I: intensity

\begin{tabular}{|c|c|c|c|c|c|c|c|c|c|}
\hline \multirow[t]{2}{*}{ Parameter } & \multicolumn{3}{|c|}{ Month - } & \multicolumn{3}{|c|}{ Locality } & \multicolumn{3}{|c|}{ Interaction } \\
\hline & df & $\chi^{2}$ & $\mathrm{p}$ & df & $\chi^{2}$ & $\mathrm{p}$ & df & $\chi^{2}$ & $\mathrm{p}$ \\
\hline LP & 1 & 140.000 & $<0.001$ & 1 & 4.114 & 0.043 & 2 & 86.995 & $<0.001$ \\
\hline GI & 1 & 91.489 & $<0.001$ & 1 & 2.118 & 0.146 & 2 & 49.634 & $<0.001$ \\
\hline P-R/CLO & 1 & 9.143 & 0.002 & 1 & 7.000 & 0.008 & 2 & 23.636 & $<0.001$ \\
\hline P-Nematopsis sp. & 1 & 2.286 & 0.131 & 1 & 3.571 & 0.059 & 2 & 15.782 & $<0.001$ \\
\hline P-Mytilicola intestinalis & 1 & 2.286 & 0.131 & 1 & 1.286 & 0.257 & 2 & 14.036 & 0.001 \\
\hline P-Intracellular ciliates & 1 & 11.571 & 0.001 & 1 & 11.571 & 0.001 & 2 & 28.145 & $<0.001$ \\
\hline P-Metacercariae & 1 & 20.571 & $<0.001$ & 1 & 20.571 & $<0.001$ & 2 & 41.891 & $<0.001$ \\
\hline P-Brown cells & 1 & 5.143 & 0.023 & 1 & 1.286 & 0.257 & 2 & 17.673 & $<0.001$ \\
\hline P-Hemocytic infiltration & 1 & 0.143 & 0.705 & 1 & 0.571 & 0.450 & 2 & 13.309 & 0.001 \\
\hline I-R/CLO & 1 & 17.286 & $<0.001$ & 1 & 15.385 & $<0.001$ & 2 & 24.275 & $<0.001$ \\
\hline I-Nematopsis sp. & 1 & 5.143 & 0.023 & 1 & 11.560 & 0.001 & 2 & 11.907 & 0.003 \\
\hline I-Mytilicola intestinalis & 1 & 27.000 & $<0.001$ & 1 & 27.000 & $<0.001$ & 2 & 40.147 & $<0.001$ \\
\hline I-Intracellular ciliates & 1 & 22.154 & $<0.001$ & 1 & 27.000 & $<0.001$ & 2 & 36.579 & $<0.001$ \\
\hline I-Metacercariae & 1 & 27.000 & $<0.001$ & 1 & 28.000 & $<0.001$ & 2 & 41.291 & $<0.001$ \\
\hline I-Brown cells & 1 & 23.148 & $<0.001$ & 1 & 11.560 & 0.001 & 2 & 25.132 & $<0.001$ \\
\hline I-Hemocytic infiltration & 1 & 26.000 & $<0.001$ & 1 & 11.636 & 0.001 & 2 & 26.000 & $<0.001$ \\
\hline
\end{tabular}


Overall, mussels presented moderately low LP values (15 to $20 \mathrm{~min}$ ), except in April, May, June and July 2005 in Oia and July 2005 in Mundaka, where LP values ranged from 10 to $15 \mathrm{~min}$ (Fig. 3A). LP values did not show a seasonal variability pattern in Oia or in Mundaka. In contrast, a continuous increasing trend was recorded over the study period, with overall significantly lower LP values in July (in Mundaka) and from April to July (in both localities) than in the remainder sampling months (Fig. 3A). Moreover, LP values were significantly higher in Mundaka than in Oia from September onwards, according to the Mann-Whitney $U$-test (Fig. 3A).

\section{Lysosomal structural changes}

According to 2-way ANOVA, $\mathrm{Vv}_{\mathrm{L}}, \mathrm{Sv}_{\mathrm{L}}, \mathrm{S} / \mathrm{V}_{\mathrm{L}}$ and $\mathrm{Nv}_{\mathrm{L}}$ varied significantly with month, locality and their interaction, except $\mathrm{Nv}_{\mathrm{L}}$ did not vary with locality (Table 2). $\mathrm{Vv}_{\mathrm{L}}$ values exhibited a similar seasonal variability pattern in both localities, with higher values in summer-autumn than in winter-spring. The highest $\mathrm{Vv}_{\mathrm{L}}$ values were recorded in Oia in December and in Mundaka 2 mo earlier, in October, whereas the lowest $\mathrm{Vv}_{\mathrm{L}}$ values were recorded in March in both localities (Fig. 3B). Exceptionally, abnormally high values were recorded in Mundaka in April 2005 (Fig. 3B). The smallest lysosomes occurred in March (Oia: $\mathrm{S} / \mathrm{V}_{\mathrm{L}}=9.1 \mu \mathrm{m}^{2} \mu \mathrm{m}^{-3}$; Mundaka: $\mathrm{S} / \mathrm{V}_{\mathrm{L}}=6.9 \mu \mathrm{m}^{2}$ $\mu \mathrm{m}^{-3}$ ), whereas $\mathrm{S} / \mathrm{V}_{\mathrm{L}}$ values were around $4 \mu^{2} \mu \mathrm{m}^{-3}$ in both localities in summer-autumn (Fig. 3C). In agreement with the high $\mathrm{VV}_{\mathrm{L}}$ values recorded, $\mathrm{S} / \mathrm{V}_{\mathrm{L}}$ values were low in Mundaka in April 2005 (Fig. 3C). A significant negative Pearson correlation coefficient was found between $\mathrm{S} / \mathrm{V}_{\mathrm{L}}$ and water surface temperature $(\mathrm{r}=-0.569 ; \mathrm{p}=0.034) . \mathrm{Nv}_{\mathrm{L}}$ presented high variability within samples and therefore significant differences between groups were rarely found. Nevertheless, mean $\mathrm{Nv}_{\mathrm{L}}$ values varied in parallel along the year in both localities with minimum mean values from July to October. Thus, despite the large variability, 2-way ANOVA revealed that both month and month $\times$ locality, but not locality, exerted a significant effect on $\mathrm{Nv}_{\mathrm{L}}$ (Table 2).

\section{Intracellular accumulation of neutral lipids}

The staining pattern for neutral lipids was heterogeneous, both within groups and within individuals. Nevertheless, overall $\mathrm{Vv}_{\mathrm{NL}}$ showed similar seasonal variability in both localities ( $\mathrm{Vv}_{\mathrm{NL}}$ significantly changed with month, locality and their interaction, according to 2 -way ANOVA; Table 2). The highest $\mathrm{Vv}_{\mathrm{NL}}$ values were recorded from November to January and more moderate maximum peaks were observed in August (Mundaka) and September (Oia) (Fig. 4). Overall, Vv $v_{\mathrm{NL}}$ values were higher in Mundaka than in Oia throughout the study period (Fig. 4).

\section{Cell-type composition in digestive gland epithelium}

Volume density of basophilic cells ( $\left.\mathrm{Vv}_{\mathrm{BAS}}\right)$ varied significantly with month, locality and their interaction according to 2-way ANOVA (Table 2). $\mathrm{Vv}_{\text {BAS }}$ was similar in Oia and Mundaka throughout the study period except in May 2005, May 2006 and July when it was higher in Oia than in Mundaka (Fig. 5A). $\mathrm{Vv}_{\text {BAS }}$ values were generally below $0.1 \mu^{3} \mu^{-3}$, except in Oia in September and May 2006, and in Mundaka in March (Fig 5A). Overall, no clear seasonal trend was apparent; on the contrary, an increase in $\mathrm{Vv}_{\mathrm{BAS}}$ values was observed during the study period, particularly in Mundaka (Fig. 5A).

Table 2. Summary of 2-way ANOVAs performed to analyse the effects of month, locality and their interaction on the studied parameters in mussels Mytilus galloprovincialis sampled in Oia and Mundaka from April 2005 to May 2006. Vv $\mathrm{V}_{\mathrm{L}}$ lysosomal volume density; $\mathrm{Sv}_{\mathrm{L}}$ : lysosomal surface density; $\mathrm{S} / \mathrm{V}_{\mathrm{L}}$ lysosomal surface to volume ratio; $\mathrm{Nv}_{\mathrm{L}}$ : lysosomal numerical density; $\mathrm{Vv}_{\mathrm{NL}}$ : volume density of intracellular neutral lipids; $\mathrm{Vv}_{\mathrm{BAS}}$ : volume density of basophilic cells; MET: mean epithelial thickness; MLR/MET: mean luminal ratio to mean epithelial thickness

\begin{tabular}{|c|c|c|c|c|c|c|c|c|c|}
\hline \multirow[t]{2}{*}{ Parameter } & \multicolumn{3}{|c|}{ Month } & \multicolumn{3}{|c|}{ Locality } & \multicolumn{3}{|c|}{-Interaction } \\
\hline & $\mathrm{df}$ & $F$ & $\mathrm{p}$ & $\mathrm{df}$ & $F$ & $\mathrm{p}$ & $\mathrm{df}$ & $F$ & $\mathrm{p}$ \\
\hline $\log \mathrm{Vv}_{\mathrm{L}}$ & 13 & 22.114 & $<0.001$ & 1 & 40.253 & $<0.001$ & 13 & 9.689 & $<0.001$ \\
\hline $\mathrm{Sv}_{\mathrm{L}}$ & 13 & 13.064 & $<0.001$ & 1 & 16.567 & $<0.001$ & 13 & 9.137 & $<0.001$ \\
\hline $\mathrm{S} / \mathrm{V}_{\mathrm{L}}$ & 13 & 30.911 & $<0.001$ & 1 & 52.458 & $<0.001$ & 13 & 10.206 & $<0.001$ \\
\hline $\log N v_{L}$ & 13 & 5.926 & $<0.001$ & 1 & 0.07 & 0.792 & 13 & 3.725 & $<0.001$ \\
\hline $\mathrm{Vv}_{\mathrm{NL}}$ & 13 & 12.022 & $<0.001$ & 1 & 26.169 & $<0.001$ & 13 & 2.307 & 0.010 \\
\hline $\mathrm{Vv}_{\mathrm{BAS}}$ & 13 & 6.017 & $<0.001$ & 1 & 6.952 & 0.009 & 13 & 2.307 & 0.007 \\
\hline MET & 13 & 22.715 & $<0.001$ & 1 & 38.095 & $<0.001$ & 13 & 3.985 & $<0.001$ \\
\hline MLR/MET & 13 & 22.942 & $<0.001$ & 1 & 56.783 & $<0.001$ & 13 & 3.138 & 0.001 \\
\hline
\end{tabular}



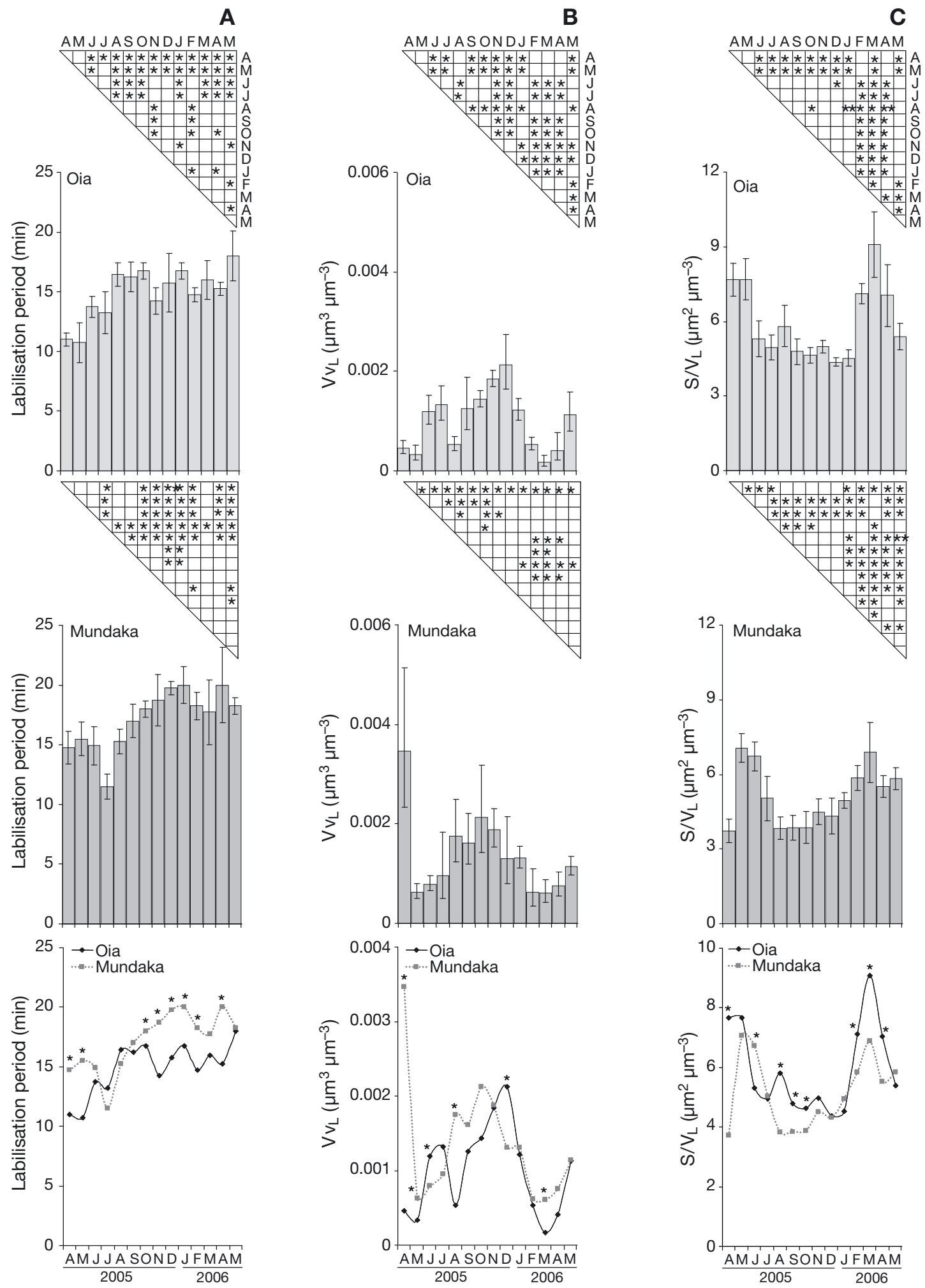

Fig. 3. Mytilus galloprovincialis. (A) Lysosomal membrane labilisation period (LP), (B) volume density ( $\mathrm{VV}_{\mathrm{L}}$ ) and (C) surface to volume ratio $\left(S / V_{L}\right)$ in digestive cells of mussels sampled monthly in Oia and Mundaka from April 2005 to May 2006. Top and center graphs - error bars: SD; asterisks in triangular matrices: significant differences $(p<0.05)$ between pairs of sampling months, according to (A) Mann-Whitney $U$-test performed after Kruskal-Wallis and (B,C) Duncan's test based on 1-way ANOVA. Bottom graphs - asterisks: significant differences $(\mathrm{p}<0.05)$ between Oia and Mundaka according to (A) Mann-Whitney $U$-test and $(\mathrm{B}, \mathrm{C})$ 


\section{Structural changes in digestive alveoli}

According to 2-way ANOVA, MET and MLR/MET significantly changed with month, locality and month $\times$ locality (Table 2). Significant differences between MLR/MET values of mussels from Oia and Mundaka were recorded in April, June, July and November 2005, and February and April 2006 (Fig. 5B). MLR/ MET values were usually between 1 and $2 \mu \mathrm{m} \mathrm{m}^{-1}$, except in February, March and May 2006 in Oia and in March 2006 in Mundaka, where values were $>2 \mu \mathrm{m}$ $\mu \mathrm{m}^{-1}$ (Fig. 5B). Overall, no clear seasonal trend was apparent; on the contrary, an increase in values was observed in both localities during the study period (Fig. 5B).

\section{Histopathology of the digestive gland}

According to Friedman's test, P and LI varied significantly with month, locality and their interaction except for Nematopsis sp., Mytilicola and hemocytic infiltration (only month $\times$ locality) and brown cell accumulation (only month and month $\times$ locality; Table 1 ). In addition, P and LI always varied significantly with month, locality and their interaction (Table 1).

In general terms, the most commonly found parasites were the gregarine Nematopsis sp. and the copepod Mytilicola intestinalis. The P and LI of both parasites were higher in Mundaka than in Oia. The highest P of Nematopsis sp. was recorded in July and October in Mundaka (Fig. 6A), whereas LI was highest in April and July 2005 and January and February 2006 (Fig. 6B). Lower-level maxima were recorded in the P of Nematopsis sp. in Oia between September and November 2005 and between February and April 2006, but LI were low. A significant positive correlation was found between the $\mathrm{P}$ of Nematopsis sp. and average monthly rainfall $\left(\mathrm{r}_{\mathrm{S}}=0.542, \mathrm{p}=0.045\right)$. $M$. intestinalis was found every month in mussels from Mundaka, but $\mathrm{P}$ and LI were always very low $(\mathrm{P}<10 \%$; $\mathrm{LI}<1)$. Eventually $\mathrm{P}$ rose moderately in April 2006 ( $\mathrm{P}=30 \%)$. In Oia, $M$. intestinalis was absent in all months except October $(\mathrm{P}=10 \%)$.

Other parasites (Rickettsia/Chlamydia-like organisms [R/CLO], intracellular ciliates and trematode metacercariae) were not very abundant. R/CLO were only occasionally recorded, and $\mathrm{P}$ was relatively low $(\mathrm{P}=$ $10 \%$ in Mundaka in July and February; P $<25 \%$ in Oia in May 2005 and 2006). Intracellular ciliates were only detected in Oia in April $2005(\mathrm{P}=10 \%)$, but in Mundaka they showed some seasonal trend with maximum peaks in spring (April 2005: $\mathrm{P}=30 \%$; May 2005: $\mathrm{P}=20 \%$; April 2006; $\mathrm{P}=30 \%$; all other months: $\mathrm{P}<$ $10 \%)$. Metacercariae were only recorded in Mundaka in April and August 2005 ( $\mathrm{P}=10$ and 20\%, respectively).

The most commonly found pathological condition was hemocytic infiltration whose P presented a similar seasonal pattern in both studied localities (Fig. 6C), characterised by a maximum peak in October, although in Oia a second maximum peak was also recorded in April 2006 (Fig. 6C). Brown cell accumulation, however, only occurred occasionally and 7 cases were recorded in Oia and 4 in Mundaka all throughout the study period.

\section{Identification of factors that explain seasonal variability}

PCA was performed on 13 biological parameters (the $\mathrm{P}$ of trematode metacercariae was excluded from the PCA because they were found only in Mundaka) (Fig. 7A). PCA was used to recognise which components explained the variability found in the measured parameters at each locality and to identify the factors that represent these components to be used in a subsequent cluster analysis. Four components explained $71.98 \%$ of the variability in Oia and $56.67 \%$ in Mundaka (Fig. 7A). The dominant variables (communality > 0.5) in Component 1 were those with one annual peak (i.e. minimum values in winter or autumn or maximum values in summer) (Fig. $7 \mathrm{~A}$ ): $\mathrm{Vv}_{\mathrm{L}}, \mathrm{Vv}_{\mathrm{NL}}$ and $\mathrm{S} / \mathrm{V}_{\mathrm{L}}$ in Oia $(\mathrm{C} 1=29.74 \%)$ and $\mathrm{VV}_{\mathrm{L}}, \mathrm{S} / \mathrm{V}_{\mathrm{L}}$ and, to a lesser extent, $\mathrm{Vv}_{\mathrm{NL}}$ (maximum peak in winter) and MLR/MET in Mundaka (minimum values in September) $(\mathrm{C} 1=19.22 \%)$. The dominant variables (communality $>0.5)$ in Component $2(\mathrm{C} 2=15.82 \%)$ in Oia were those showing a continuous trend throughout the year with maximum peaks in spring and/or autumn (GI and P of hemocytic infiltration; Fig. 7A) and in Mundaka those that varied markedly between sampling months but did not present a seasonal pattern (LP and the P of Nematopsis sp.; C2 $=14.53 \%$ ). The dominant variables (communality $>0.5$ ) in Component 3 in Oia were those that did not present a seasonal pattern $\left(\mathrm{VV}_{\mathrm{BAS}}\right.$, MLR/MET and LP; C3 $\left.=15.67 \%\right)$ and in Mundaka those with maximum peaks in spring (GI and $\mathrm{P}$ of intracellular ciliates; $\mathrm{C} 3=12.38 \%$ ). The dominant variables (communality $>0.5$ ) in Component 4 were those that did not present either large variability or a seasonal pattern: the P of Nematopsis sp. in Oia $(\mathrm{C} 4=10.74 \%)$ and $\mathrm{VV}_{\mathrm{BAS}}$ and $\mathrm{P}$ of brown cells in Mundaka $(\mathrm{C} 4=10.54 \%)$. Each main component represents a different seasonal variation pattern in biomarkers, as illustrated in Fig. 7B.

$\mathrm{LP}, \mathrm{VV}_{\mathrm{L}}, \mathrm{VV}_{\mathrm{BAS}}$ and the $\mathrm{P}$ of hemocytic infiltration, Nematopsis sp., and intracellular ciliates were the variables that contributed most strongly to each of these 4 

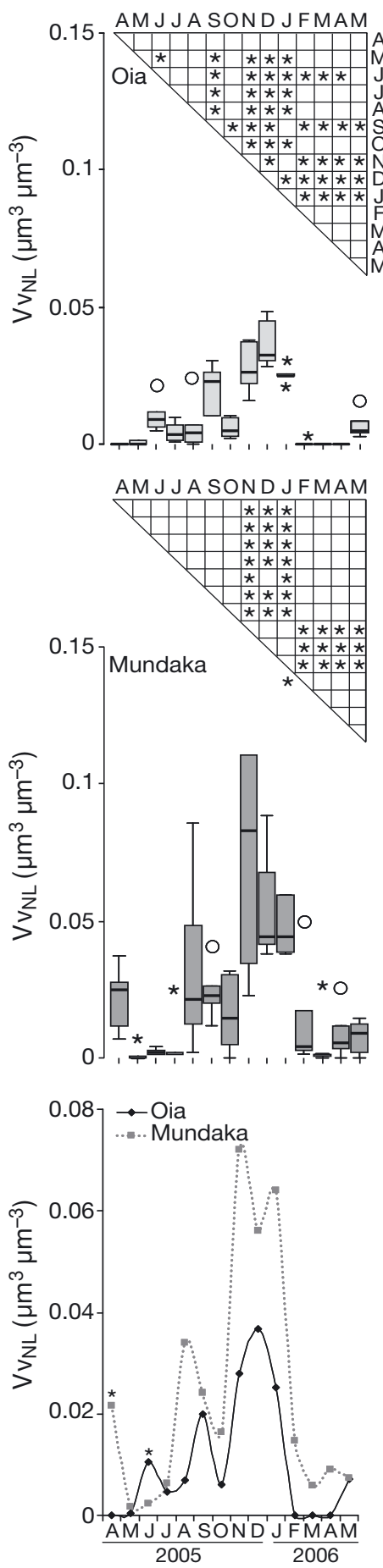

Fig. 4. Mytilus galloprovincialis. Volume density of intracellular neutral lipids $\left(\mathrm{Vv}_{\mathrm{NL}}\right)$ in digestive gland of mussels sampled monthly in Oia and Mundaka from April 2005 to May 2006. Top and center graphs-error bars: quartiles; horizontal lines in bars: median values; circles and asterisks: mild and severe outsiders, respectively; asterisks in the triangular matrices: significant differences (Duncan's test based on 1-way ANOVA, $\mathrm{p}<0.05$ ) between pairs of sampling months. Bottom graphs - * significant differences (Student's $t$-test, p < 0.05) between Oia and Mundaka

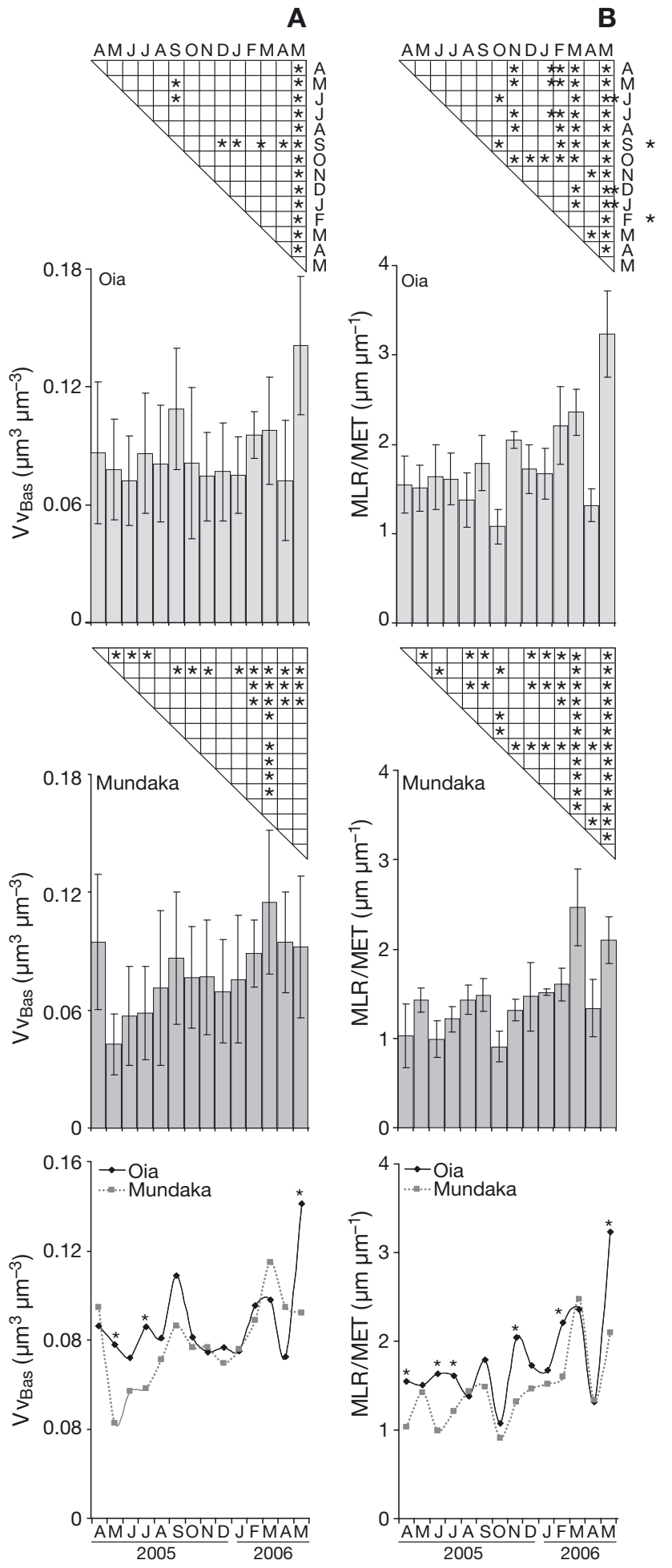

Fig. 5. Mytilus galloprovincialis. (A) Volume density of basophilic cells $\left(\mathrm{Vv}_{\mathrm{BAS}}\right)$ and (B) mean luminal ratio to mean epithelial thickness (MLR/MET) in digestive gland epithelium of mussels sampled monthly in Oia and Mundaka from April 2005 to May 2006. Top and center graphs - error bars: $\mathrm{SD}_{\text {; }}$ asterisks in triangular matrices: significant differences (Duncan's test based on 1-way ANOVA, p < 0.05 ) between pairs of sampling months. Bottom graphs - * significant differences (Student's $t$-test, $\mathrm{p}<0.05$ ) between Oia and Mundaka 

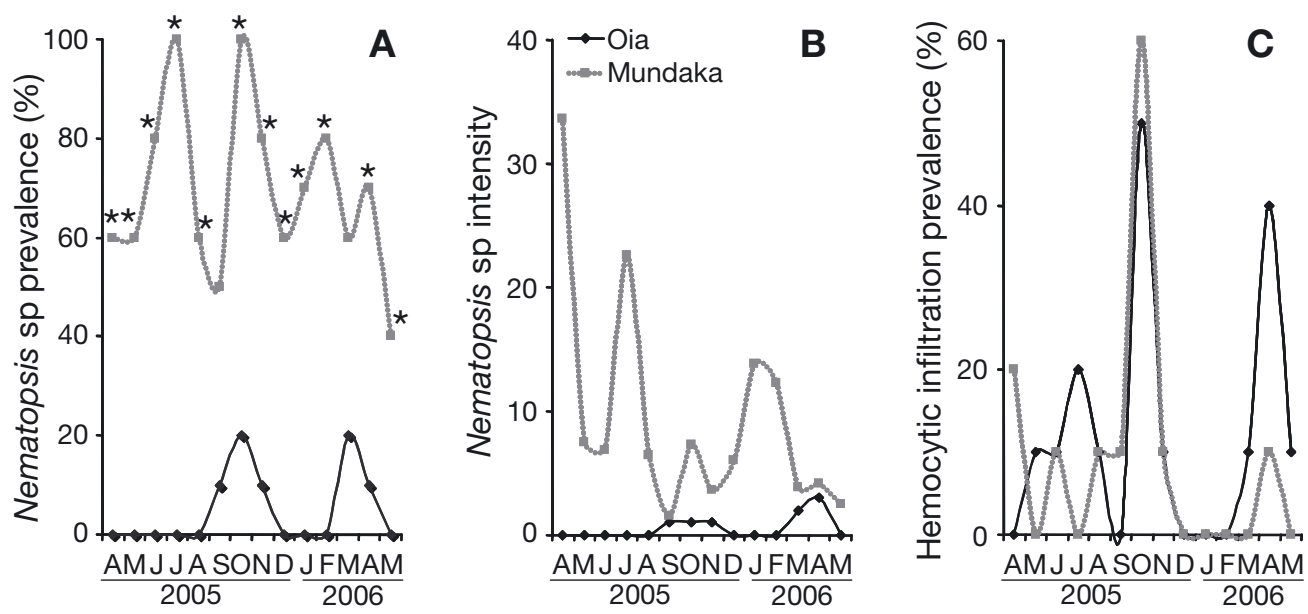

Fig. 6. Mytilus galloprovincialis. Histopathology of the digestive gland of mussels sampled monthly in Oia and Mundaka from April 2005 to May 2006. (A) Prevalence (\%) of Nematopsis sp.; (B) infection intensity (mean parasites host ${ }^{-1}$ ) of Nematopsis sp.; (C) prevalence of hemocytic infiltrations. * Significant differences $\left(\chi^{2}\right.$ test, $\left.\mathrm{p}<0.05\right)$ between mussels from Oia and Mundaka

principal components and were hence selected to perform a hierarchical cluster analyses in order to classify sampling months for both localities according to the seasonal variability pattern of the biological variables recorded in each case (Fig. 8A). Overall, July to March samples of both localities and June 2005 and May 2006 in Oia belong to the same cluster, indicated in green in the diagrammatic scheme constructed on the basis of the cluster analysis to illustrate temporal and spatial trends in the suite of biomarkers as a whole (Fig. 8B). April and May in Oia, and June in Mundaka comprise a significantly distinct clustering (orange in Fig. 8B); whereas April, July and October 2005 in Mundaka were outsiders (indicated by different colours in Fig. 8B).

\section{DISCUSSION}

A battery of exposure and effect biomarkers was applied in mussels collected monthly in Oia (Galicia) and Mundaka (Basque Coast) from April 2005 to May 2006. For all the parameters recorded in the present study, except for the $\mathrm{P}$ of pathogens and LI, presumptive baseline reference values are currently available (Marigómez et al. 2006; Table 3), but they are of limited significance since they correspond to one-off studies carried out in few localities from a restricted area of the Basque Coast. Thus the values obtained in the present study constitute an invaluable set of baseline values for biomarkers to be applied in monitoring programmes conducted to assess the biological effects of pollution (i.e. after the POS) in the North Iberian Peninsula (Galicia and Biscay Bay).
Gamete developmental stages were recorded as supporting parameters, and were evaluated by determining gamete developmental phases after examination of tissue sections (Kim et al. 2006). Gamete development can follow a similar seasonal trend in distant localities at a different geographical sites, but seasonal patterns may be different in nearby localities (Villalba 1995, Orbea et al. 2006) or vary annually in the same locality (Ortiz-Zarragoitia \& Cajaraville 2010). Indeed, environmental conditions largely influence the gametogenic cycle in mussels, differences due to food availability being considered a major exogenous factor affecting the reproductive or gametogenic cycle (Newell et al. 1982, Rodhouse et al. 1984). Presently, both localities showed a similar gametogenic cycle throughout the studied period, which is in agreement with previous reports. In M. galloprovincialis from Galicia, gametogenesis has been reported to progress in autumn and early winter using reserves stored during the previous summer and first half of autumn (Villalba 1995). The most remarkable difference was that, unlike in Oia where one spawning period took place, a rapid gonad restoration was observed after spawning in Mundaka with a second spawning peak between September and October. This difference is probably due to higher phytoplankton concentration found in the Basque Coast that particular year. In previous studies only one spawning has been observed in a locality close to Mundaka (Ortiz-Zarragoitia \& Cajaraville 2010).

Digestive cell lysosomes are very sensitive to a wide range of contaminants and their responses are widely used as general stress or effect biomarkers of pollution, both in field and laboratory studies (Moore 1988, Regoli 1992, Etxeberria et al. 1994, 1995, Cajaraville et al. 1995, Marigómez et al. 1996, Marigómez \& Baybay- 

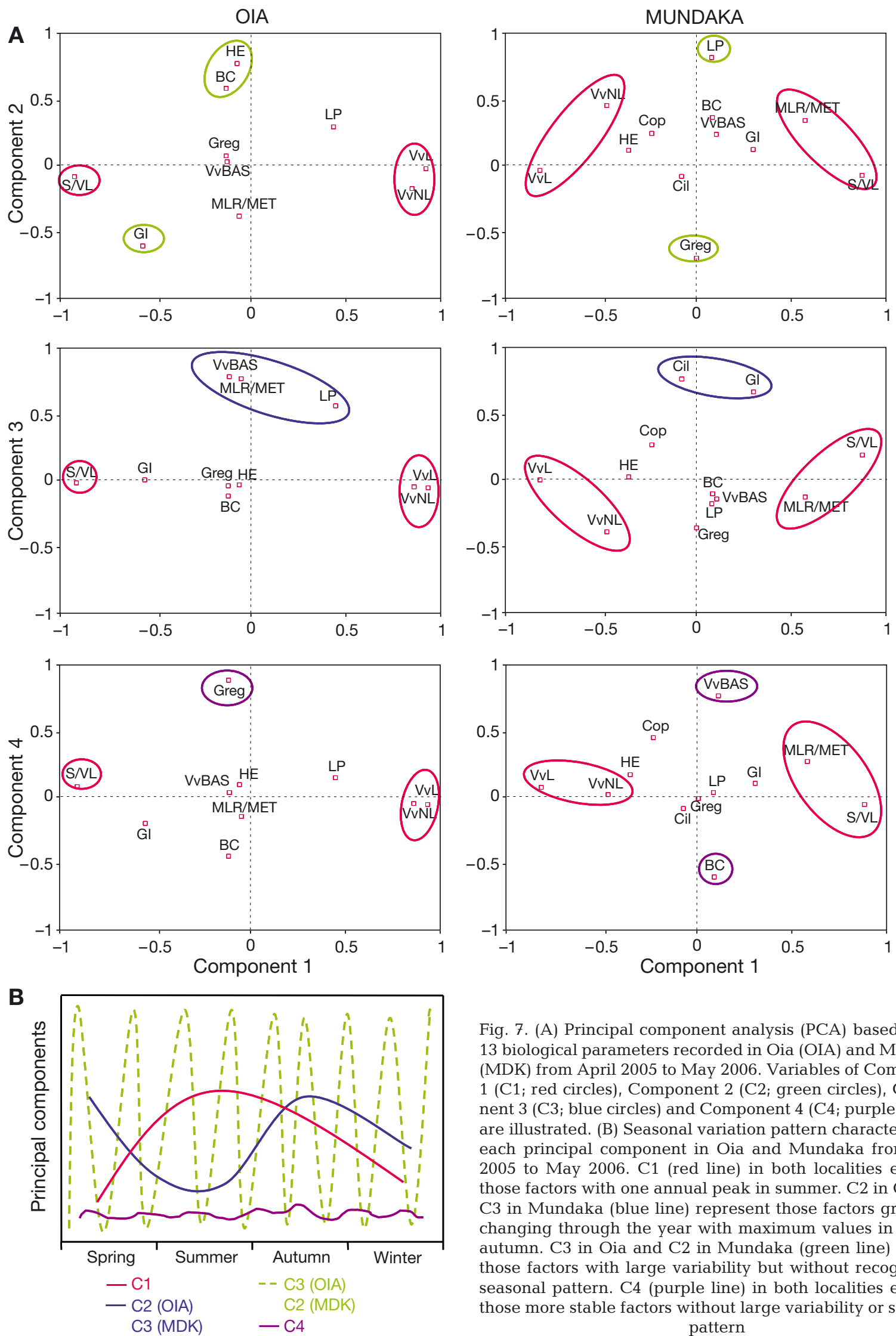

Fig. 7. (A) Principal component analysis (PCA) based on the 13 biological parameters recorded in Oia (OIA) and Mundaka (MDK) from April 2005 to May 2006. Variables of Component 1 (C1; red circles), Component 2 (C2; green circles), Component 3 (C3; blue circles) and Component 4 (C4; purple circles) are illustrated. (B) Seasonal variation pattern characteristic of each principal component in Oia and Mundaka from April 2005 to May 2006. C1 (red line) in both localities explains those factors with one annual peak in summer. $\mathrm{C} 2$ in Oia and C3 in Mundaka (blue line) represent those factors gradually changing through the year with maximum values in spring/ autumn. C3 in Oia and C2 in Mundaka (green line) refer to those factors with large variability but without recognisable seasonal pattern. C4 (purple line) in both localities explains those more stable factors without large variability or seasonal pattern 

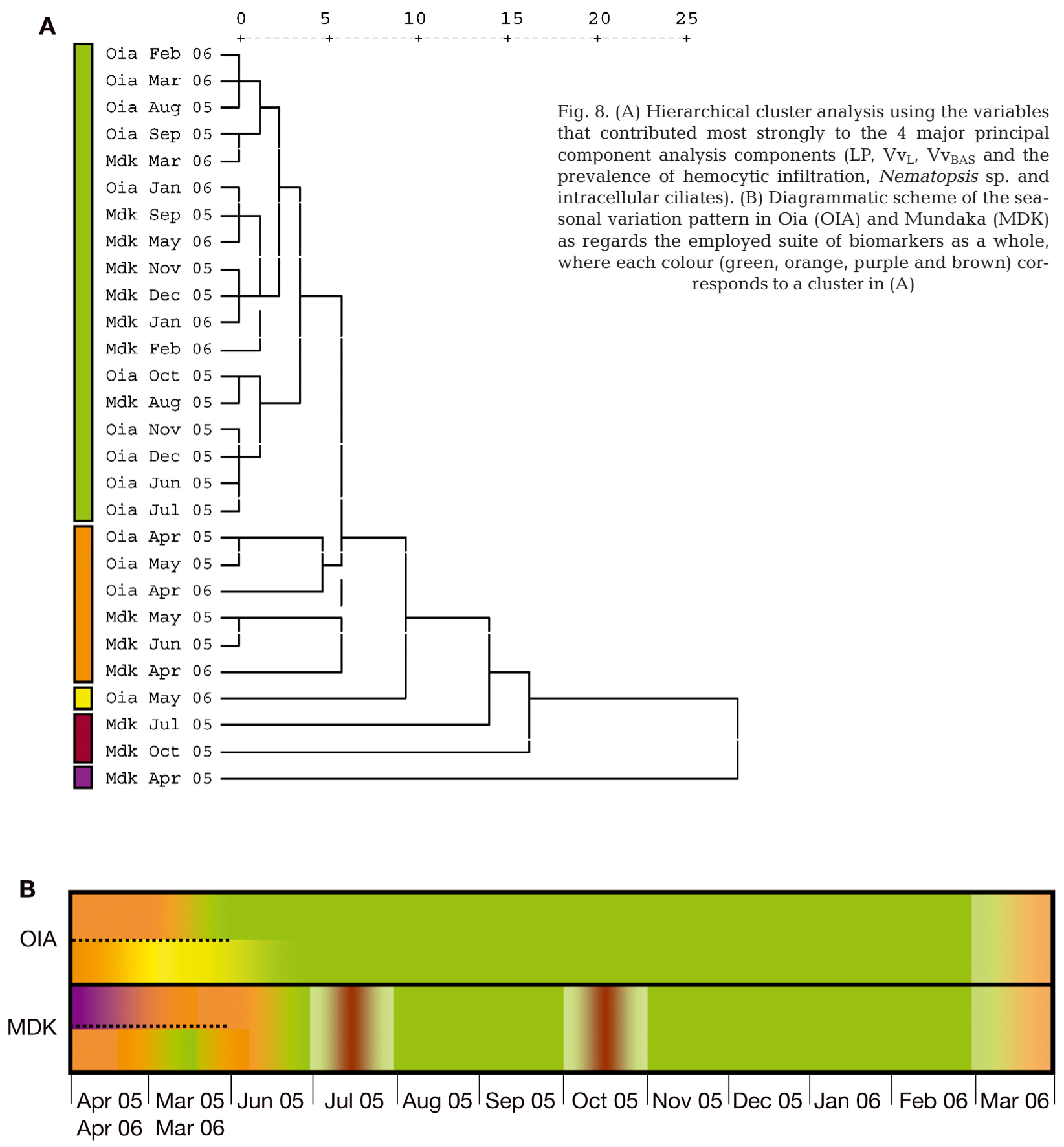

Villacorta 2003). In the present study, lysosomal alterations were measured as changes in volume, surface and numerical density and membrane stability. The lysosomal membrane stability test is recommended by the OSPAR Convention to assess the biological effects of contaminants (Stagg 1998, UNEP/RAMOGE 1999). In mussels, LP values higher than 20 to 25 min indicate a healthy status, whereas LP values $<10$ min indicate a disturbed health or severe stress situation (Viarengo et al. 2000, Izagirre \& Marigómez 2009) which has been reported, for example, after exposure to organo- chemical compounds (Moore et al. 1987). In the present study, LP values >15 min were recorded in most sampling months in Oia and most markedly in Mundaka, evidencing a moderate health status of mussels. The fact that LP was always under reference values (20 to $25 \mathrm{~min}$ ) in both localities could explain the lack of a seasonal variability pattern. Indeed, a seasonal pattern in lysosomal membrane stability has been reported in hemocytes (Bocchetti \& Regoli 2006) and digestive cells (Petrović et al. 2004) of mussels from the Adriatic Sea and in digestive cells of mussels from the Basque 
Table 3. Presumptive baseline reference values corresponding to all the parameters recorded in the present study, except for the prevalence and infection intensity of pathogens and pathological lesions. LP: labilisation period of the lysosomal membrane; $\mathrm{Vv}_{\mathrm{L}}$ : lysosomal volume density; $\mathrm{S} / \mathrm{V}_{\mathrm{L}}$ lysosomal surface to volume ratio; $\mathrm{Vv}_{\mathrm{NL}}$ : volume density of intracellular neutral lipids; MLR/MET: mean luminal ratio to mean epithelial thickness; $\mathrm{Vv}_{\mathrm{BAS}}$ : volume density of basophilic cells; ND: not detectable

\begin{tabular}{|c|c|c|c|c|c|c|}
\hline Parameter & Month & Year & $\begin{array}{c}\text { Reference values } \\
\text { before POS } \\
\text { (Marigómez et al. 2006) }\end{array}$ & Site & $\begin{array}{c}\text { Oia } \\
\text { after POS } \\
\text { (Galician coast) }\end{array}$ & $\begin{array}{c}\text { Mundaka } \\
\text { after POS } \\
\text { (Basque coast) }\end{array}$ \\
\hline LP (min) & $\begin{array}{l}\text { April } \\
\text { July } \\
\text { October }\end{array}$ & $\begin{array}{l}2005 / 2006 \\
2005 \\
2005\end{array}$ & $\begin{array}{l}>20 \\
>20 \\
>20\end{array}$ & Gorliz & $\begin{array}{c}11-15.25 \\
13.25 \\
16.75\end{array}$ & $\begin{array}{c}14.75-20 \\
11.5 \\
18\end{array}$ \\
\hline $\mathrm{Vv}_{\mathrm{L}}\left(\mu \mathrm{m}^{3} \mu \mathrm{m}^{-3}\right)$ & $\begin{array}{c}\text { April } \\
\text { July } \\
\text { October }\end{array}$ & $\begin{array}{l}2005 / 2006 \\
2005 \\
2005\end{array}$ & $\begin{array}{c}0.0005 \\
0.002 \\
0.002\end{array}$ & Plentzia & $\begin{array}{c}0.00045-0.00041 \\
0.0013 \\
0.0014\end{array}$ & $\begin{array}{c}0.0034-0.00075 \\
0.00095 \\
0.0021\end{array}$ \\
\hline $\mathrm{S} / \mathrm{V}_{\mathrm{L}}\left(\mu \mathrm{m}^{2} \mu \mathrm{m}^{-3}\right)$ & $\begin{array}{c}\text { April } \\
\text { July } \\
\text { October }\end{array}$ & $\begin{array}{l}2005 / 2006 \\
2005 \\
2005\end{array}$ & $\begin{array}{c}8 \\
5 \\
4.5-5\end{array}$ & Plentzia & $\begin{array}{c}7.67-7.03 \\
4.95 \\
4.63\end{array}$ & $\begin{array}{c}3.72-5.51 \\
5.03 \\
3.86\end{array}$ \\
\hline $\mathrm{Vv}_{\mathrm{NL}}\left(\mu \mathrm{m}^{3} \mu \mathrm{m}^{-3}\right)$ & $\begin{array}{c}\text { April } \\
\text { July } \\
\text { October }\end{array}$ & $\begin{array}{l}2005 / 2006 \\
2005 \\
2005\end{array}$ & $\begin{array}{c}0.005 \\
0.005 \\
0.05-0.1\end{array}$ & Plentzia & $\begin{array}{c}\text { ND } \\
0.0045 \\
0.0059\end{array}$ & $\begin{array}{c}0.021-0.0091 \\
0.0062 \\
0.016\end{array}$ \\
\hline MLR/MET $\left(\mu \mathrm{m} \mu \mathrm{m}^{-1}\right)$ & $\begin{array}{l}\text { April } \\
\text { July } \\
\text { October }\end{array}$ & $\begin{array}{l}2005 / 2006 \\
2005 \\
2005\end{array}$ & $\begin{array}{l}0.7 \\
0.7 \\
1.2\end{array}$ & Urdaibai & $\begin{array}{c}1.54-1.31 \\
1.62 \\
1.07\end{array}$ & $\begin{array}{c}1.03-1.33 \\
1.21 \\
0.90\end{array}$ \\
\hline $\mathrm{Vv}_{\mathrm{BAS}}\left(\mu \mathrm{m}^{3} \mu \mathrm{m}^{-3}\right)$ & $\begin{array}{c}\text { April } \\
\text { July } \\
\text { October }\end{array}$ & $\begin{array}{l}2005 / 2006 \\
2005 \\
2005\end{array}$ & $\begin{array}{c}0.05 \\
0.1 \\
0.05\end{array}$ & Plentzia & $\begin{array}{c}0.086-0.072 \\
0.086 \\
0.081\end{array}$ & $\begin{array}{c}0.094-0.094 \\
0.058 \\
0.076\end{array}$ \\
\hline
\end{tabular}

Coast (Izagirre et al. 2008), although in a study carried out in mussels from the Mediterranean Sea LP was not significantly different between May and October (Zorita et al. 2007). Thus the lack of seasonal variability observed in the present study might be indicative of persistence of the POS effects on lysosomal membrane integrity beyond those recorded for 2 to $3 \mathrm{yr}$ after the spill (Cajaraville et al. 2006, Marigómez et al. 2006, Orbea et al. 2006), although LP values tend to increase up to values indicative of a healthy status after longterm effects (Fig. 3).

Likewise, the assessment of lysosomal dimensions provides valuable indication of general environmental stress (Cajaraville et al. 2000, Marigómez \& BaybayVillacorta 2003). Pollutant exposure results in lysosomal enlargement in mussels' digestive cells (Etxeberria et al. 1994, 1995, Cajaraville et al. 1995, Marigómez et al. 1996, 2005, Marigómez \& Baybay-Villacorta 2003), although it may also provoke a reduction in lysosomal size and numbers (Marigómez et al. 1996, Marigómez \& Baybay-Villacorta 2003). In general terms, $\mathrm{Vv}_{\mathrm{L}}$ and $\mathrm{S} / \mathrm{V}_{\mathrm{L}}$ values recorded in Oia and Mundaka were similar to those previously reported for the Basque Coast. Thus the smallest lysosomes were recorded in winter/ early spring (when water surface temperature was lowest) and the largest were recorded in summer (Etxeberria et al. 1995, Marigómez et al. 1996, Izagirre et al. 2008), although the maximum $\mathrm{VV}_{\mathrm{L}}$ peak in Mundaka occurred 2 mo prior to that in Oia. Excep- tionally, lysosomal enlargement was observed in Mundaka in April 2005, which seems to indicate some environmental disturbance may be related to the consequences of the POS or any isolated pollution event (Marigómez et al. 1996, 2005, Marigómez \& BaybayVillacorta 2003).

Exposure to organic xenobiotics may result in intracellular accumulation of neutral lipids (Moore 1988, Lowe \& Clarke 1989, Regoli 1992, Marigómez \& Baybay-Villacorta 2003). Such accumulation of neutral lipids constitutes an all-or-nothing response, as ORO staining is usually heterogeneous both within individuals and within groups, leading to a very high variability in $\mathrm{Vv}_{\mathrm{NL}}$ (Marigómez \& Baybay-Villacorta 2003). In the present study, both localities showed similar seasonal variability, although in general terms higher $\mathrm{Vv}_{\mathrm{NL}}$ values were detected in Mundaka than in Oia in most sampling months. Again, this could be related to higher phytoplankton concentrations found on the Basque Coast compared to Galicia. The highest $\mathrm{Vv}_{\mathrm{NL}}$ values were recorded from November to February, in parallel with the beginning of the gametogenesis cycle that, in the studied localities, began in October (Fig. 2).

In mussel digestive gland epithelium, 2 types of cells are distinguished: digestive and basophilic cells (Marigómez et al. 1998, Dimitriadis et al. 2004). Digestive cells are characterized by a well-developed endolysosomal system. Basophilic cells are secretory cells which are involved in the synthesis and secretion of 
proteins for extracellular digestion. Basophilic cells are usually less abundant than digestive cells, but under stress situations an apparent increase in the relative numbers of basophilic cells occurs (Rasmussen et al. 1983, Lowe \& Clarke 1989, Cajaraville et al. 1990, Zorita et al. 2006). This apparent cell type replacement is the result of digestive cell loss and concomitant basophilic cell hypertrophy (Zaldibar et al. 2007) and is measured in terms of $\mathrm{Vv}_{\text {BAS. }}$. Digestive cell loss may cause disturbances in food digestion and xenobiotic accumulation (Marigómez et al. 1998). In reference localities on the Basque coast, $\mathrm{Vv}_{\text {BAS }}$ values were $<0.1 \mu^{3} \mu^{-3}$, but under stress situations values $>0.2 \mu \mathrm{m}^{3} \mu^{-3}$ have been reported (Cajaraville et al. 1990, Cajaraville et al. 2006, Marigómez et al. 2006). In the present study, in both localities $\mathrm{Vv}_{\mathrm{BAS}}$ values were close to reference values, and they did not exhibit a seasonal variability pattern.

Atrophy of the digestive alveoli may be provoked by different stress sources (Lowe et al. 1981, Lowe \& Clarke 1989, Vega et al. 1989, Cajaraville et al. 1992), which can be measured using different planimetric parameters such as MET, mean diverticular radius (MDR), MLR and the ratios MLR/MET and MET/MDR (Vega et al. 1989). The thickness of digestive gland epithelium may change depending on natural environmental stressors (malnutrition, saline, thermal and post-spawning stress; Bayne et al. 1978) as well as after exposure to pollutants (Lowe et al. 1981, Lowe \& Clarke 1989, Vega et al. 1989, Cajaraville et al. 1992). In the present study, MLR/MET was selected as it is the most sensitive of the aforementioned 5 planimetric parameters (Vega et al. 1989). MLR/MET presented a similar pattern of variability in both localities, characterised by minimum values in September and October, in agreement with previous data (Méndez 1993, Díez 1996). However, values were slightly lower in Mundaka than in Oia. Moreover, since MLR/MET values were $>1.2 \mu \mathrm{m} \mathrm{m}^{-1}$ throughout the studied period, it seems that mussels were subjected to some source of environmental stress (Cajaraville et al. 1992, Marigómez et al. 2006). Although a recovery trend was apparent after July 2005 (Cajaraville et al. 2006), MLR/MET did not fully return to prePOS conditions in 2006 (Garmedia 2008).

Histopathological alterations are useful to assess the general health status of sentinel molluscs and hence ecosystem health (Kim et al. 1998). Mussels commonly harbour parasites and diseases of a variety of types that can significantly affect their health and fecundity (Pérez Camacho et al. 1997). The most important parasites observed in the present study (R/CLO, Nematopsis sp. and Mytilicola intestinalis) are not considered harmful to mussels (Sindermann 1990). R/CLO were detected within digestive cells, but their P and LI were low in both localities. Nematopsis sp. was observed in the connective tissue around the digestive tubules. They are not pathogenic to mussels, albeit heavy infections may be harmful (Sindermann 1990). M. intestinalis is a parasitic (commensal rather than harmful) copepod in the intestine of mussels (Gresty 1992), which mainly affects adults. In general, P and LI of Nematopsis sp. and M. intestinalis were higher in Mundaka than in Oia. Thus histopathological condition was not similar between both localities, but $\mathrm{P}$ and LI was low and thus not considered harmful to mussel health. Overall, the P of brown cells in both localities and Nematopsis sp. in Oia did not show seasonality, whereas hemocytic infiltration in both localities and ciliates in Mundaka varied together with gamete development, and Nematopsis sp. was highly variable through the year in Mundaka.

Seasonal variability pattern was explained by 4 principal components after PCA. The first component included factors with one annual peak $\left(\mathrm{Vv}_{\mathrm{L}}, \mathrm{Vv}_{\mathrm{NL}}\right.$ and $\mathrm{S} / \mathrm{V}_{\mathrm{L}}$ in Oia and $\mathrm{Vv}_{\mathrm{L}}, \mathrm{S} / \mathrm{V}_{\mathrm{L}}, \mathrm{Vv}_{\mathrm{NL}}$ and MLR/MET in Mundaka). The second component comprised factors showing a progressing seasonal trend throughout the year (GI and P of hemocytic infiltration in Oia, and LP and P of Nematopsis sp. in Mundaka). The third component included those factors without a clear seasonal pattern $\left(\mathrm{Vv}_{\mathrm{BAS}}\right.$, MLR/MET and LP in Oia and GI [2 spawning peaks] and $\mathrm{P}$ of intracellular ciliates in Mundaka). The factors included in the fourth component were those that presented neither large variability nor a seasonal pattern ( $P$ of Nematopsis sp. in Oia and $\mathrm{V}_{\mathrm{V}_{\mathrm{BAS}}}$ and $\mathrm{P}$ of brown cells in Mundaka). $L P, V_{V_{L}}, V_{v_{B A S}}$ and the $P$ of hemocytic infiltration, Nematopsis sp. and intracellular ciliates were the variables that contributed most strongly to these 4 principal components.

After cluster analysis, we concluded that overall, July to March samples of both localities, and June 2005 and May 2006 samples from Oia, were similar regarding the integrative characterisation by the parameters studied. Accordingly, when a suite of biomarkers is employed, the significance of the seasonal variability of individual biomarkers is inconsequential for assessing pollution effects and therefore biomarkers can be used throughout the whole year (Kagley et al. 2003). On the other hand, April and May in Oia, and June in Mundaka were similar to each other but different from the rest of the months of the year. This distinct period may be related to the critical period associated with the end of the gametogenic cycle, spawning and the beginning of summer when somatic feeding and somatic growth are enhanced (Etxeberria et al. 1995, Villalba 1995, Marigómez et al. 1996, Cancio et al. 1999). Similarly, seasonal variability in temperature and food availability, both governing the reproductive cycle, explained most of the observed natural variability in biomarkers in mussels and clams from the Baltic 
Sea (Leiniö \& Lehtonen 2005). Likewise, in Corbicula fluminea, most seasonal changes in biomarkers were related to critical moments of the reproductive cycle and/or water temperature (Vidal et al. 2002). Thus, although occasionally the eventual occurrence of parasites may act as a confounding factor, in general terms only 2 different periods are distinguished throughout an annual cycle: from late March to early June (reproductive stress) and from late June to early March. Consequently, considering the low signal and responsiveness of biomarkers in winter (Marigómez et al. 1996, Etxeberria et al. 1994, Orbea et al. 2002, Izagirre et al. 2008) together with the present results regarding seasonal trends, we recommend that for long-term biomarker-based pollution monitoring with sentinel mussels in the North Iberian Peninsula, organisms are sampled twice per year, once in the spring period (March-June) and once during autumn, as in the Mediterranean Sea (Zorita et al. 2007).

\section{CONCLUSIONS}

Overall, the present study provides baseline values that can be used as reference values for the biomonitoring programmes carried out in coastal areas from Galicia to the Basque Coast to assess the biological effects of the POS (Cajaraville et al. 2006, Marigómez et al. 2006, Orbea et al. 2006) or other acute or chronic pollution events. The present study shows that most studied biomarkers and certain histopathological conditions have a seasonal variability pattern that was similar in the 2 selected localities in Galicia and the Basque Coast. We conclude that seasonality is crucial for the design and interpretation of results in Mussel Watch monitoring programmes based on biomarkers; sampling of mussels before and after the reproduction period will allow studies to cover most seasonal variability in studied biomarkers and histopathological conditions.

Acknowledgements. This work was supported by the Spanish Ministry of Science and Technology through Urgent ActionCoastal areas and project PRESTEPSE (vem2003-20082-CO601), by the Basque Government (ETORTEK actions IMPRES and K-EGOKITZEN) and by the University of the Basque Country through a grant to Consolidated Research Groups. The technical assistance of the personnel of the Cell Biology and Histology Lab (Faculty of Science and Technology, University of the Basque Country) in samplings and sample processing is gratefully acknowledged.

\section{LITERATURE CITED}

Bayne BL, Holland DL, Moore MN, Lowe DM, Widdows J (1978) Further studies on the effects of stress in the adult on the eggs of Mytilus edulis. J Mar Biol Assoc UK 58: 825-841
Bignell JP, Dodge MJ, Feist SW, Lyons B and others (2008) Mussel histopathology: effects of season, disease and species. Aquat Biol 2:1-15

Bocchetti R, Regoli F (2006) Seasonal variability of oxidative biomarkers, lysosomal parameters, metallothioneins and peroxisomal enzymes in the Mediterranean mussel Mytilus galloprovincialis from Adriatic Sea. Chemosphere 65: 913-921

Bocchetti R, Lamberti CV, Pisanelli B, Razzetti EM and others (2008) Seasonal variations of exposure biomarkers, oxidative stress responses and cell damage in the clams, Tapes philippinarum, and mussels, Mytilus galloprovincialis, from Adriatic Sea. Mar Environ Res 66:24-26

> Cajaraville MP, Díez G, Marigómez IA, Angulo E (1990) Responses of the basophilic cells of the digestive gland of mussels to petroleum hydrocarbon exposure. Dis Aquat Org 9:221-228

Cajaraville MP, Marigómez IA, Angulo E (1991) Automated measurement of lysosomal structure alterations in oocytes of mussels exposed to petroleum hydrocarbons. Arch Environ Contam Toxicol 21:395-400

> Cajaraville MP, Marigómez I, Díez G, Angulo E (1992) Comparative effects of the water accommodated fraction of three oils on mussels. 2. Quantitative alterations in the structure of the digestive tubules. Comp Biochem Physiol 102:113-123

> Cajaraville MP, Abascal I, Etxeberria M, Marigómez I (1995) Lysosomes as cellular markers of environmental pollution: time- and dose-dependent responses of the digestive lysosomal system of mussels after petroleum hydrocarbon exposure. Environ Toxicol Water Qual 10:1-8

Cajaraville MP, Bebianno MJ, Blasco J, Porte C, Sarasquete C, Viarengo A (2000) The use of biomarkers to assess the impact of pollution in coastal environments of the Iberian Peninsula: a practical approach. Sci Total Environ 247: 295-311

Cajaraville MP, Cancio I, Ibabe A, Orbea A (2003) Peroxisome proliferation as a biomarker in environmental pollution assessment. Microsc Res Tech 61:191-202

Cajaraville MP, Garmendia L, Orbea A, Werding R and others (2006) Signs of recovery of mussels' health two years after the Prestige oil spill. Mar Environ Res 62:S337-S341

Cancio I, Ibabe A, Cajaraville MP (1999) Seasonal variation of peroxisomal enzyme activities and peroxisomal structure in mussels Mytilus galloprovincialis and its relationship with the lipid content. Comp Biochem Physiol 123: 135-144

Culling CFA (1974) Handbook of histopathological and histochemical techniques, 3rd edn. Butterworths, London

Díez G (1996) Correlación multiespecífica entre biomarcadores celulares de estrés ambiental y niveles biodisponibles de contaminantes orgánicos y metálicos: un estudio de campo. PhD dissertation, University of the Basque Country, Bilbao

> Dimitriadis VK, Domouhtsidou GP, Cajaraville MP (2004) Cytochemical and histochemical aspects of the digestive gland cells of the mussel Mytilus galloprovincialis (L.) in relation to function. J Mol Histol 35:501-509

> Etxeberria M, Sastre I, Cajaraville MP, Marigómez I (1994) Digestive lysosome enlargement induced by experimental exposure to metals $(\mathrm{Cu}, \mathrm{Cd}$ and $\mathrm{Zn})$ in mussels collected from a zinc-polluted site. Arch Environ Contam Toxicol $27: 338-345$

- Etxeberria M, Cajaraville MP, Marigómez I (1995) Changes in digestive cell lysosomal structure in mussels as biomarkers of environmental stress in the Urdaibai Estuary (Biscay coast, Iberian Peninsula). Mar Pollut Bull 30:599-603 
García-Soto G, Pingree R, Valdés L (2002) Navidad development in the Southern Bay of Biscay: climate change swoddy structure from remote sensing and in situ measurements. J Geophys Res C 107:3118

Garmendia L (2008) Monitoring of the Prestige oil spill biological effects based on the biomarker approach: mussel watch from Galicia to Basque coast. PhD Thesis, University of the Basque Country, Leioa

Gresty KA (1992) Ultrastructure of the midgut of the copepod Mytilicola intestinalis Steuer, an endoparasite of the mussel Mytilus edulis L. J Crustac Biol 12:169-177

Hillman RE (1993) Gonadal index and histopathology for the East and West coasts used in the National Status and Trends Mussel Watch Project. In: Sampling and analytical methods of the National Status and Trends Program National Benthic Surveillance and Mussel Watch Projects 1984-1992, Vol II. Comprehensive descriptions of complementary measurements. NOAA Tech Mem NOS ORCA 71. NOAA/NOS/ORCA, Silver Spring, MD, p 45-53

Ivankovic D, Pavicic J, Erk M, Filipovic-Marijic V, Raspor B (2005) Evaluation of the Mytilus galloprovincialis Lam. digestive gland metallothionein as a biomarker in a longterm field study: seasonal and spatial variability. Mar Pollut Bull 50:1303-1313

> Izagirre U, Marigómez I (2009) Lysosomal enlargement and lysosomal membrane destabilisation in mussel digestive cells measured by an integrative index. Environ Pollut 157:1544-1553

Izagirre U, Ramos RR, Marigómez I (2008) Natural variability in size and membrane stability of lysosomes in mussel digestive cells: seasonal and tidal zonation. Mar Ecol Prog Ser 372:105-117

Kagley AN, Snider RG, Krishnakumar PK, Casillas E (2003) Assessment of seasonal variability of cytochemical responses to contaminant exposure in blue mussel Mytilus edulis (Complex). Arch Environ Contam Toxicol 44:43-52

Kim Y, Powell EN, Wade TL, Presley BJ, Sericano J (1998) Parasites of sentinel bivalves in the NOAA Status and Trend Program: distribution and relationship to contaminant body burden. Mar Pollut Bull 37:45-55

Kim Y, Ashton-Alcox A, Powell EN (2006) Histological techniques for marine bivalve molluscs: update. NOAA Tech Memo NOS NCCOS 27. NOAA, Silver Spring, MD

Leiniö S, Lehtonen KK (2005) Seasonal variability in biomarkers in the bivalves Mytilus edulis and Macoma balthica from the northern Baltic Sea. Comp Biochem Physiol 140C:408-421

Lowe DM, Clarke KR (1989) Contaminant-induced changes in the structure of the digestive epithelium of Mytilus edulis. Aquat Toxicol 15:345-358

Lowe DM, Moore MN, Clarke KR (1981) Effects of oil on digestive cells in mussels: quantitative alterations in cellular and lysosomal structure. Aquat Toxicol 1:213-226

Marigómez I, Baybay-Villacorta L (2003) Pollutant-specific and general lysosomal responses in digestive cells of mussels exposed to model organic chemicals. Aquat Toxicol 64:235-257

Marigómez I, Orbea A, Olabarrieta I, Etxeberria M, Cajaraville MP (1996) Structural changes in the digestive lysosomal system of sentinel mussels as biomarkers of environmental stress in Mussel Watch programs. Comp Biochem Physiol 113:291-297

Marigómez I, Cajaraville MP, Soto M, Lekube X (1998) Cell type replacement, a successful strategy of molluscs to adapt to chronic exposure to pollutants. Cuad Invest Biol 20:411-414

Marigómez I, Lekube X, Cajaraville MP, Domouhtsidou G,
Dimitriadis V (2005) Comparison of cytochemical procedures to estimate lysosomal biomarkers in mussel digestive cells. Aquat Toxicol 75:86-95

> Marigómez I, Soto M, Cancio I, Orbea A, Garmendia L, Cajaraville MP (2006) Cell and tissue biomarkers in mussel, and histopathology in hake and anchovy from Bay of Biscay after the Prestige oil spill (Monitoring Campaign 2003). Mar Pollut Bull 53:287-304

McCarthy JF, Shugart LR (1990) Biological markers of environmental contamination. In: McCarthy JF, Shugart LR (eds) Biomarkers of environmental contamination. Lewis, Boca Raton, FL, p 3-14

Méndez PA (1993) Composición celular y estructura tisular de la glándula digestiva de mejillones en un programa de seguimiento de la contaminación en el estuario de El Abra. MSc thesis, Univerity of the Basque Country, Leioa

Moore MN (1988) Cytochemical responses of the lysosomal system and NADPH-ferrihemoprotein reductase in molluscan digestive cells to environmental and experimental exposure to xenobiotics. Mar Ecol Prog Ser 46:81-89

Moore MN, Pipe RK, Farrar SV (1987) Induction of lysosomal lipid accumulation and fatty degeneration by polycyclic aromatic hydrocarbons in molluscan digestive cells. Mar Environ Res 4:352-353

Newell RIE, Hilbish TJ, Koehn RK, Newell CJ (1982) Temporal variation in the reproductive cycle of Mytilus edulis L (Bivalvia, Mytilidae) from localities on the East coast of the United States. Biol Bull 162:299-310

Oehlmann J, Schulte-Oehlmann U (2003) Molluscs as bioindicators. In: Markert BA, Breure AM, Zechmeister HG (eds) Bioindicators and biomonitorings. Elsevier, New York, p 577-635

Orbea A, Cajaraville MP (2006) Peroxisome proliferation and antioxidant enzymes in transplanted mussels of four Basque estuaries with different levels of PAH and PCB pollution. Environ Toxicol Chem 25:1616-1626

Orbea A, Ortiz-Zarragoitia M, Porte C, Cajaraville MP (2002) Antioxidant enzymes and peroxisome proliferation in relation to contaminant body burdens of PAHs and PCBs in bivalve molluscs, crabs and fish from the Urdaibai and Plentzia estuaries (Bay of Biscay). Aquat Toxicol 58:75-98

Orbea A, Garmendia L, Marigómez I, Cajaraville MP (2006) Effects of the 'Prestige' oil spill on cellular biomarkers in intertidal mussels: results of the first year of studies. Mar Ecol Prog Ser 306:177-189

Ortiz-Zarragoitia M, Cajaraville MP (2010) Intersex and oocyte atresia in a mussel population from the biosphere's reserve of Urdaibai (Bay of Biscay). Ecotoxicol Environ Saf (in press)

Pérez Camacho A, Villalba A, Beiras R, Labarta U (1997) Absorption efficiency and condition of cultured mussels (Mytilus edulis galloprovincialis Linnaeus) of Galicia (NW Spain) infected by parasites Marteilia refringens Grizel et al. and Mytilicola intestinalis Steur. J Shellfish Res 16:77-82

Petrović S, Semencic L, Ozretic B, Ozretic M (2004) Seasonal variations of physiological and cellular biomarkers and their use in the biomonitoring of North Adriatic coastal waters (Croatia). Mar Pollut Bull 49:713-720

Rasmussen LP, Hage E, Karlog O (1983) Histopathological studies of the acute and chronic toxic effects of $2 \mathrm{~N}$-nitroso compounds on the blue mussel (Mytilus edulis). Nord Vet Med 35:306-313

Regoli F (1992) Lysosomal responses as a sensitive stress index in biomonitoring heavy metal pollution. Mar Ecol Prog Ser 84:63-69

$>$ Rodhouse PG, Roden CM, Burnell GM, Hensey MP, McMahon T, Ottway B, Ryan TH (1984) Food resources, gameto- 
genesis and growth of Mytilus edulis on the shore and in suspended culture: Killary Harbour, Ireland. J Mar Biol Assoc UK 64:513-529

Shaw JP, Large AT, Donkin P, Evans SV and others (2004) Seasonal variation in cytochrome P450 immunopositive protein levels, lipid peroxidation and genetic toxicity in digestive gland of the mussel Mytilus edulis. Aquat Toxicol 67:325-336

Sindermann CJ (1990) Principal diseases of marine fish and shellfish, 2nd edn, Vol 2. Academic Press, San Diego, CA

Sokal RR, Rohlf FJ (1995) Biometry: the principles and practice of statistics in biological research, 3rd edn. WH Freeman, New York

Soto M, Zaldibar B, Cancio I, Taylor MG, Turner M, Morgan AJ, Marigómez I (2002) Subcellular distribution of cadmium and its cellular ligands in mussel digestive gland as revealed by combined autometallography and X-ray microprobe analysis. Histochem J 34:273-280

Stagg RM (1998) The development of an international program for monitoring the biological effects of contamination in the OSPAR convention area. Mar Environ Res 46: 307-313

Svärdh L, Johannesson K (2002) Incidence of hemocytes and parasites in coastal populations of blue mussels (Mytilus edulis) - testing correlations with area, season, and distance to industrial plants. J Invertebr Pathol 80:22-28

UNEP/RAMOGE (1999) Manual on the biomarkers recommended for the MED POL biomonitoring program. UNEP, Athens

Vega MM, Marigómez I, Angulo E (1989) Quantitative alterations in the structure of digestive cells of Littorina littorea

Editorial responsibility: Hans Heinrich Janssen, Oldendorf/Luhe, Germany on exposure to cadmium. Mar Biol 103:547-553

Verlecar XN, Jena KB, Chainy GBN (2008) Seasonal variation of oxidative biomarkers in gills and digestive gland of green-lipped mussel Perna viridis from Arabian Sea. Estuar Coast Shelf Sci 76:745-752

Viarengo A, Lafaurie M, Gabrielides GP, Fabbri R, Marro A, Romeo M (2000) Critical evaluation of an intercalibration exercise undertaken in the framework of the MED POL biomonitoring program. Mar Environ Res 49:1-18

Vidal ML, Bassères A, Narbonne JF (2002) Seasonal variations of pollution biomarkers in two populations of Corbicula fluminea (Müller). Comp Biochem Physiol C 131: 133-151

Villalba A (1995) Gametogenic cycle of cultured mussel, Mytilus galloprovincialis, in the bays of Galicia (NW Spain). Aquaculture 130:269-277

Weibel ER (1979) Stereological methods. Academic Press, London

Zaldibar B, Cancio I, Marigómez I (2007) Reversible alterations in epithelial cell turnover in digestive gland of winkles (Littorina littorea) exposed to cadmium and their implications for biomarker measurements. Aquat Toxicol 81:183-196

Zorita I, Ortiz-Zarragoitia M, Soto M, Cajaraville MP (2006) Biomarkers in mussels from a copper site gradient (Visnes, Norway): an integrated biochemical, histochemical and histological study. Aquat Toxicol 78(Suppl 1):S109-S116

Zorita I, Apraiz I, Ortiz-Zarragoitia M, Orbea A and others (2007) Assessment of biological effects of environmental pollution along the NW Mediterranean Sea using mussels as sentinel organisms. Environ Pollut 148:236-250

Submitted: November 11, 2009; Accepted: March 8, 2010 Proofs received from author(s): May 18, 2010 